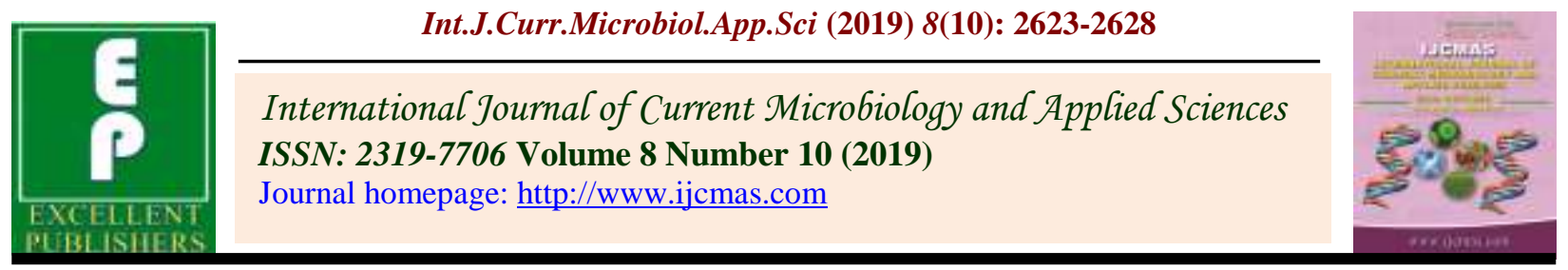

Original Research Article

https://doi.org/10.20546/ijcmas.2019.810.302

\title{
Seasonal Variation of Soil Chemical Characteristics at Agriculture Technical School, Manjri Farm, Pune, India
}

\author{
G. K. Yadav ${ }^{1 *}$, A. D. Jagdhani ${ }^{1}$, D. D. Sawale ${ }^{1}$, M. K. Krishnapriya ${ }^{1}$ and R. S. Yadav ${ }^{2}$ \\ ${ }^{1}$ Department of Soil Science and Agricultural Chemistry, \\ College of Agriculture, Pune-411 005, India \\ ${ }^{2}$ ICAR-IISWC, RC Datia-475 661, India \\ *Corresponding author
}

\section{Keywords}

Technical, Season, Parameter

Article Info

Accepted:

25 September 2019

Available Online:

10 October 2019
The article presents an overview of impact of seasonal variation on soil nutrient quality at Agriculture Technical School, Manjri Farm, Pune, Maharashtra, India during year 2018-2019. Total 94 surface soil samples $(0-22.5 \mathrm{~cm}$ depth) were collected in pre-monsoon (April-2018) and post-monsoon (October-2018) season.The chemical parameter viz., pH, EC, organic carbon, calcium carbonate, available nitrogen, phosphorus, potassium, sulphur and DTPA extractable micronutrients iron, manganese, zinc and copper, were $7.52,0.36 \mathrm{dSm}^{-1}, 0.68$, 5.90 per cent, $216.71,11.56,363.0 \mathrm{~kg} \mathrm{ha}^{-1}, 9.34 \mathrm{mg} \mathrm{kg}^{-1}$ and $0.98,8.43,3.47$ and $5.60 \mathrm{mg} \mathrm{kg}^{-1}$, respectively in pre-monsoon season. In post-monsoon, the $\mathrm{pH}, \mathrm{EC}$, organic carbon, calcium carbonate, available nitrogen, phosphorus, potassium, sulphur and DTPA extractable micronutrients iron, manganese, zinc and copper, were $7.58,0.40 \mathrm{dSm}^{-1}, 0.72,5.38$ per cent, 205.80, 10.70, $358.25 \mathrm{~kg} \mathrm{ha}^{-1}, 10.20$ $\mathrm{mg} \mathrm{kg}^{-1}$ and $1.01,8.45,3.39$ and $5.82 \mathrm{mg} \mathrm{kg}^{-1}$, respectively. The soil chemical properties $\mathrm{pH}, \mathrm{EC}$, organic carbon, available sulphur, iron, manganese and copper were high in post-monsoon season while calcium carbonate available nitrogen, phosphorus, potassium and zinc were high in pre-monsoon season.

\section{Introduction}

Soils are basic to Civilization Supplying various economic and cultural services as well as being the subtract for plant and with water it constitute society's most important, source as a life support system. They provide food, fiber, support building and road help to convert sunlight to usable forms of energy and other resource. Soil the outermost layers of the earth is a product of geological processes and human intervention. Soils are integral and vital part of our environment and may be defined as discrete bodies produced by interaction of climate, vegetation and surficial geological materials on earth Surface. It is 
composed of minerals altered physically and chemically from original bed rock, organic chemicals and biomass and pore space fill with air water and dissolved material. The quality and security of soil have always affected human civilization. Man has made soil fertile on large scale, providing more source food resource for the ever-growing population. Soil is one of the vital resources on the planet earth. Soil is an important system of terrestrial ecosystem, and direct discharge of industrial effluents especially those without any treatment may influence the physico-chemical and biological properties of soil related to soil fertility (Kumar et al., 2012).

In the recent years, considerable attention has been paid to disposal of industrial waste, which is usually discharged on land or into the water sources. Inherent soil physico-chemical properties influence the behavior of soil and hence, knowledge of soil property is important.

\section{Materials and Methods}

Agriculture Technical School, Manjri Farm, Pune, comes under plain zone of Maharashtra and is located at $18^{0} 29^{\prime}$ to $18^{0} 30^{\prime} \mathrm{N}$ latitude and $73^{\circ} 58^{\prime}$ to $73^{0} 59^{\prime}$ E longitude. The elevation from mean sea level is $562 \mathrm{~m}$. The area under cultivation is 43.04 ha out of which 27.84 ha area under lift farm and 15.20 ha under central farm. The climate is usually hot and is classified as semiarid tropical the annual rainfall $545 \mathrm{~mm}$. The mean maximum temperature ranged between $34^{0} \mathrm{C}$ to $42^{\circ} \mathrm{C}$ while annual mean minimum temperature varies from $8^{0} \mathrm{C}$ to $20^{\circ} \mathrm{C}$. The mean humidity percentage ranged between $78-95$ percent. The soil samples were collected from fields and allowed to dry completely in a shade. After drying the samples they were grind carefully in wooden mortar and pestle and passed from $2 \mathrm{~mm}$ sieve and $0.5 \mathrm{~mm}$ sieve for special determination like soil organic carbon, then stored in bags with proper labeling and were used for further analysis.

\section{Results and Discussion}

The chemical analysis of soil is given in tables 1,2 and 3 .

\section{Soil Reaction (pH)}

The $\mathrm{pH}$ of soil varied from 6.96 to 8.70 with an average value of 7.52 in pre-monsoon and in post-monsoon it was ranged from 7.00 to 8.75 with a mean value of 7.58 . These soils were 'slightly alkaline" to 'moderately alkaline' as per the standard ratings. In postmonsoon season, the soil $\mathrm{pH}$ is increased as compared pre-monsoon season. Due to addition of rain water. (Solanki and Chavda 2012 and Dev et al.,2017).

\section{Electrical Conductivity (EC)}

The electrical conductivity of soil in premonsoon varied from 0.19 to $0.69 \mathrm{dSm}^{-1}$ with an average value of $0.36 \mathrm{dSm}^{-1}$ and in postmonsoon it was ranged from 0.22 to 0.71 with a mean value of $0.40 \mathrm{dSm}^{-1}$. These soils were low in soluble salts as per the standard ratings. The electrical conductivity higher in postmonsoon season as compared to pre-monsoon season. When the water content increases electrical conductivity also increases (Kumar and Srikantaswamy. 2012 and Dev et al., 2017).

\section{Organic Carbon (OC)}

The organic carbon in soil in pre-monsoon and post-monsoon season ranged from 0.37 to 0.96 per cent with a mean value 0.68 per cent and 0.45 to 0.98 per cent with an average value 0.72 per cent, respectively indicating that the soils were 'moderate' to 'moderately high' in organic carbon content. The organic carbon 
higher inpost-monsoon season as compared to pre-monsoon season, because wetland soil has more organic carbon content than terrestrial soil because presences of soil microorganism are responsible for decomposition of organic matter (Ingavale et al., 2012; Kumar and Srikantaswamy, 2012).

\section{Calcium Carbonate $\left(\mathrm{CaCO}_{3}\right)$}

The calcium carbonate in soil in pre-monsoon and post-monsoon season ranged from 2.75 to 8.50 per cent with a mean value 5.90 per cent and 2.50 to 8.00 per cent with an average value 5.38 per cent, respectively. These soils were 'moderate" to "moderately high' in calcium carbonate content as per the standard ratings. The calcium carbonate higher in premonsoon season as compared to postmonsoon season, because in post-monsoon season carbonate leached out with rainfall water (Kumar and Srikantaswamy, 2012).

\section{Available Nitrogen, Phosphorus, Potassium and Sulphur (N, P, K, and S)}

The available nitrogen in soil, in pre-monsoon ranged from 137.90 to $288.15 \mathrm{~kg} \mathrm{ha}^{-1}$ with a mean value of $216.71 \mathrm{~kg} \mathrm{ha}^{-1}$ in post-monsoon it ranged from 112.89 to $275.96 \mathrm{~kg} \mathrm{ha}^{-1}$ with an average value of $205.80 \mathrm{~kg} \mathrm{ha}^{-1}$. These soils were 'very low' to 'low' in available nitrogen content as per the standard ratings.

In pre-monsoon season the available nitrogen content is higher than post-monsoon season, due to mineralization of organic carbon that have released large amount of nitrogen in soil. (Dev et al.,2017).

The available phosphorus Inpre-monsoon ranged from 7.49 to $18.90 \mathrm{~kg} \mathrm{ha}^{-1}$ with a mean value of $11.56 \mathrm{~kg} \mathrm{ha}^{-1}$ in post-monsoon it ranged from 6.20 to $17.44 \mathrm{~kg} \mathrm{ha}^{-1}$ with an average value of $10.70 \mathrm{~kg} \mathrm{ha}^{-1}$. These soils were 'low' to 'medium' in available phosphorus contain as per the standard ratings. In pre-monsoon season the available phosphorus content is higher than postmonsoon season, might be due to assimilation of phosphorus from the water by phytoplankton would find to release more phosphorus from the sediments (Dev et al.,2017).

The available potassium in soil during premonsoon ranged from 238.56 to $624.96 \mathrm{~kg}$ ha ${ }^{1}$ with a mean value of $363.0 \mathrm{~kg} \mathrm{ha}^{-1}$ in postmonsoon it ranged from 234.23 to $620.79 \mathrm{~kg}$ $\mathrm{ha}^{-1}$ with an average value of $358.25 \mathrm{~kg} \mathrm{ha}^{-1}$. These soils were 'moderately high' to "very high' in available potassium content as per the standard ratings. In post-monsoon season the potassium content decreased in soil as compared to pre-monsoon season, in rainy season the potassium present in soil is easily dissolved in water and eroded off and solubility of potassium in rainy season is higher than in dry season (Kumar and Srikantaswamy, 2012; Dev et al., 2017). The available sulphurin pre-monsoon ranged from 6.24 to $11.75 \mathrm{mg} \mathrm{kg}^{-1}$ with a mean value of $9.34 \mathrm{mg} \mathrm{kg}^{-1}$ in post-monsoon it ranged from 7.15 to $13.23 \mathrm{mg} \mathrm{kg}^{-1}$ with an average value of $10.37 \mathrm{mg} \mathrm{kg}^{-1}$. These soils are 'low' to 'medium' in available sulphur content as per the standard ratings. In post-monsoon season the sulphur content was higher than premonsoon season, due to rainfall might have added a significant amount of atmospheric sulphur in soil. (Wang et al., 2005 and Dev et al.,2017).

DTPA Extractable Micronutrient Iron, Manganese, Zinc and Copper (Fe, Mn, Zn and $\mathrm{Cu}$ )

The available iron in soil for pre-monsoon ranged from 0.60 to $3.51 \mathrm{mg} \mathrm{kg}^{-1}$ with a mean value of $0.98 \mathrm{mg} \mathrm{kg}^{-1}$ in post-monsoon it ranged from 0.61 to $3.54 \mathrm{mg} \mathrm{kg}^{-1}$ with an average value of $1.01 \mathrm{mg} \mathrm{kg}^{-1}$. 
Table.1 Status of $\mathrm{pH}, \mathrm{EC}, \mathrm{OC}$, and $\mathrm{CaCO}_{3}$

\begin{tabular}{|c|c|c|c|c|}
\hline & pH & $\underset{\left(\mathbf{d S m}^{-1}\right)}{\mathrm{EC}}$ & $\begin{array}{l}\text { OC } \\
(\%)\end{array}$ & $\begin{array}{c}\mathrm{CaCO}_{3} \\
(\%)\end{array}$ \\
\hline \multicolumn{5}{|c|}{ Pre-monsoon } \\
\hline Range & $6.96-8.70$ & $0.19-0.69$ & $0.37-0.96$ & $2.75-8.50$ \\
\hline Average & 7.52 & 0.36 & 0.68 & 5.90 \\
\hline SD & 0.39 & 0.11 & 0.18 & 1.28 \\
\hline \multicolumn{5}{|c|}{ Post-monsoon } \\
\hline Range & $7.00-8.75$ & $0.22-0.71$ & $0.45-0.98$ & $2.50-8.00$ \\
\hline Average & 7.58 & 0.40 & 0.72 & 5.38 \\
\hline SD & 0.38 & 0.11 & 0.17 & 1.21 \\
\hline
\end{tabular}

Table.2 Status of available nitrogen, phosphorus, potassium and sulphur

\begin{tabular}{|c|c|c|c|c|}
\hline & $\begin{array}{l}\text { Available } \\
\text { nitrogen } \\
\left(\mathbf{k g ~ h a}^{-1}\right)\end{array}$ & $\begin{array}{c}\text { Available } \\
\text { phosphorus } \\
\left(\mathbf{k g ~ h a}^{-1}\right)\end{array}$ & $\begin{array}{l}\text { Available } \\
\text { potassium } \\
\left.\text { (kg ha }^{-1}\right)\end{array}$ & $\begin{array}{l}\text { Available } \\
\text { sulphur } \\
\left(\mathrm{mg} \mathrm{kg}^{-1}\right)\end{array}$ \\
\hline \multicolumn{5}{|c|}{ Pre-monsoon } \\
\hline Range & $137.90-288.15$ & 7.49-18.90 & $238.56-624.96$ & $6.24-11.75$ \\
\hline Average & 216.71 & 11.56 & 363.00 & 9.34 \\
\hline SD & 38.85 & 2.92 & 78.74 & 1.62 \\
\hline \multicolumn{5}{|c|}{ Post-monsoon } \\
\hline Range & $112.89-275.96$ & $6.20-17.44$ & $234.23-620.79$ & $7.15-13.23$ \\
\hline Average & 205.80 & 10.70 & 358.25 & 10.37 \\
\hline SD & 40.16 & 2.85 & 78.04 & 1.81 \\
\hline
\end{tabular}

Table.3 Status of available micronutrient

\begin{tabular}{|c|c|c|c|c|}
\hline \multicolumn{5}{|c|}{ Available micronutrient $\left(\mathbf{m g ~ k g}^{-1}\right)$} \\
Manganese \\
\hline \multicolumn{5}{|c|}{ Pre-monsoon } \\
\hline Range & $0.60-3.51$ & $0.76-18.4$ & $0.91-7.76$ & $2.43-11.16$ \\
\hline Average & 0.98 & 8.43 & 3.47 & 5.60 \\
\hline SD & 0.43 & 6.35 & 2.43 & 2.87 \\
\hline & \multicolumn{4}{|c|}{ Copper } \\
\hline Range & $0.61-3.54$ & $0.77-18.41$ & $0.92-7.79$ & $2.59-11.91$ \\
\hline Average & 1.01 & 8.45 & 3.39 & 5.82 \\
\hline SD & 0.44 & 6.35 & 2.37 & 2.91 \\
\hline Critical limit & $\mathbf{4 . 5}$ & $\mathbf{2 . 0}$ & $\mathbf{0 . 6}$ & $\mathbf{0 . 2}$ \\
\hline
\end{tabular}


All the soil samples collected from Agriculture Technical School, Manjri Farm, Pune, was deficient in available iron, as the critical limit of available iron is $4.5 \mathrm{mg} \mathrm{kg}^{-1}$ (Takkar et al., 1989 and Patel et al., 2015).

The available manganese in soil during premonsoon ranged from 0.76 to $18.40 \mathrm{mg} \mathrm{kg}^{-1}$ with a mean value of $8.43 \mathrm{mg} \mathrm{kg}^{-1}$ in postmonsoon it ranged from 0.77 to $18.41 \mathrm{mg} \mathrm{kg}^{-1}$ with an average value of $8.45 \mathrm{mg} \mathrm{kg}^{-1}$. All the soil samples collected from Agriculture Technical School, Manjri Farm, Pune, was sufficient in available manganese, as the critical limit of available iron is $2 \mathrm{mg} \mathrm{kg}^{-1}$ (Takkar et al., 1989 and Patel et al., 2015).

The available zinc in soil during pre-monsoon ranged from 0.91 to $7.76 \mathrm{mg} \mathrm{kg}^{-1}$ with a mean value of $3.47 \mathrm{mg} \mathrm{kg}^{-1}$ in post-monsoon it ranged from 0.92 to $7.79 \mathrm{mg} \mathrm{kg}^{-1}$ with an average value of $3.39 \mathrm{mg} \mathrm{kg}^{-1}$. All the soil samples collected from Agriculture Technical School, Manjri Farm, Pune, was sufficient in available zinc, as the critical limit of available zinc is $0.6 \mathrm{mg} \mathrm{kg}^{-1}$ (Katyal et al., 1985 and Solanki and Chavda 2012).

The available copper in soil during premonsoon ranged from 2.43 to $11.16 \mathrm{mg} \mathrm{kg}^{-1}$ with a mean value of $5.60 \mathrm{mg} \mathrm{kg}{ }^{-1}$ in postmonsoon it ranged from 2.59 to $11.91 \mathrm{mg} \mathrm{kg}^{-1}$ with an average value of $5.82 \mathrm{mg} \mathrm{kg}^{-1}$. All the soil samples collected from Agriculture Technical School, Manjri Farm, Pune, was sufficient in available copper, as the critical limit of available copper is $0.2 \mathrm{mg} \mathrm{kg}^{-1}$. (Katyal et al., 1985, Patel et al., 2015, Solanki and Chavda. 2012).

The soil chemical properties $\mathrm{pH}, \mathrm{EC}$, organic carbon, available sulphur, iron, manganese and copper were high in post-monsoon season while calcium carbonate available nitrogen, phosphorus, potassium and Zinc were high in pre-monsoon season. The soil of Agriculture
Technical School, Manjri Farm, Pune were alkaline in nature, low in soluble salts, moderate to moderately high in organic carbon and calcium carbonate, very low to low in available nitrogen, low to medium in phosphorus and sulphur, moderately high to very high in potassium and DTPA extractable micronutrient were sufficient in soil except iron.

\section{Acknowledgement}

Authors are thankful to Dr. R.S. Yadav, Principle Scientist ICAR-IISWC, RC Datia, for formulating plan of work and kind cooperation in technical and scientific guidance during the experimentation.

\section{References}

Dev, M.K., Panda, A., Tigga, B. and Prakash, K J. (2017).Study of physic-chemical properties of industrial zone soil from lote M.I.D.C, Maharashtra, India.Plant Archives 17, 187-190.

Ingavale, R.R., Mohite, S.A., Shinde, T.V., Jadhav, A.S. and Raut, P.D. (2012) Studied on physico-chemical characteristics of soil of Bhagawati river bank in Kolhapur district, Maharashtra. International conference SWRDM.

Katyal, J.C. (1985) Research achievement of all India co-ordinate scheme of micronutrient in soil and plants. Journal of Indian Society of Soil Science 52, 142-143.

Kumar V., Chopra A.K. and Chauhan R.K. (2012) Effect of textile effluents disposal on water quality of sub canal of upper Ganga at Haridwar (Uttarakhand), India.Journal of Chemical and Pharmaceutical Research4, 4206-4211.

Kumar S.D. and Srikantaswamy S. (2012).Study of physic-chemical 
characteristics of industrial zone soil of Mysore city, Karnataka, India. International Journal of Environmental Science3, 224-232.

Patel J.B. and Das A. (2015).Assessing toxic metal contamination in soil, water and plant bodies around an Industrial belt. International Journal of Research in Applied, Natural and Social Science 3, 5-20.

Solanki H.A. and Chavda, C. (2012). Studied the physico-chemical analysis with reference to seasonal change in soil at
Victoria Park Reserve Forest, Bhavnagar, Gujarat. Life Science Leaflets8, 62-68.

Takkar, P.N., Chhibba, I.M. and Mehta, S.K. (1989) Twenty years of coordinated research on micronutrients in soils and plants. Bulletin of Indian Institute of Soil Science 1, 76.

Wang T.J., Yang H.M., Geo L.J., Zhang, Y. and Xu, C.K. (2005) Atmospheric sulphur deposition in farmland in East China. Pedosphere, 15, 120-128.

\section{How to cite this article:}

Yadav, G. K., A. D. Jagdhani, D. D. Sawale, M. K. Krishnapriya and Yadav, R. S. 2019. Seasonal Variation of Soil Chemical Characteristics at Agriculture Technical School, Manjri Farm, Pune, India. Int.J.Curr.Microbiol.App.Sci. 8(10): 2623-2628. doi: https://doi.org/10.20546/ijcmas.2019.810.302 